ISSN 0103-5150

Fisioter. Mov., Curitiba, v. 28, n. 1, p. 85-95, Jan./Mar. 2015

Licenciado sob uma Licença Creative Commons

DOI: http://dx.doi.org.10.1590/0103-5150.028.001.A009

\title{
Healthy preterm infants: global motor coordination and early intervention
}

\author{
Crianças pré-termo saudáveis: coordenação \\ motora global e intervenção precoce
}

\author{
Alice Sá Carneiro Ribeiro ${ }^{[a]}$, Cibelle Kayenne Martins Roberto Formiga ${ }^{[b]}$, Ana Cristina de David ${ }^{[\mathrm{c}] *}$ \\ [a] Centro Integrado Tiradentes (Unit), Maceió, AL, Brazil \\ [b] Universidade Estadual de Goiás (UEG), Goiânia, GO, Brazil \\ [c] Universidade de Brasília (UnB), Brasília, DF, Brazil
}

\begin{abstract}
Introduction: Studies recommend a participation by preterm children (PT) in Early Intervention Programs (EIP), as the coordination dysfunctions appear to occur more frequently in premature school children. Objectives: Describe the global motor coordination (MC) in PT children that participate in an EIP; verify the difference in MC between the sexes and correlate the coordination results of PT children and those with gestation age (GA) and the birth weight (BW); and compare the results of MC between PT children and full-term children (FT). Materials and methods: 57 children (5-6 years old) - 20 PT that participate in EIP, and 37 FT. For the analysis of MC, it was used the Körperkoordination für Kinder (KTK) - Test of Body Coordination for Children. To the comparisons, it was used independent-samples T-test and the Mann-Whitney test ( $\alpha=0.05)$, and the Pearson correlation to verify the influence of GA and BW in the coordinated results. Results: $80 \%$ of the PT children presented normal MC; the girls demonstrated a better performance on the tasks balance
\end{abstract}

\footnotetext{
* ASCR: MSc, e-mail: alicesacarneiro@gmail.com CKMRF: PhD, e-mail: cibellekayenne@gmail.com ACD: PhD, e-mail: acdavid@unb.br
} 
beam and lateral jumps and with regard to the MC corresponding to the sum of the gross scores on the tasks; the GA and BW did not influence MC; and, there was no difference between MC in PT and FT children. Conclusion: The PT children presented, in their majority, satisfactory levels of MC, and the girls presented better results. In addition, the GA and BW did not interfere in the MC results. Lastly, there was no difference in the coordination performance between PT and FT children.

Keywords: Coordination. Motor skills. Premature. Child.

\section{Resumo}

Introdução: Estudos indicam a participação de crianças pré-termo (PT) em programas de intervenção precoce (PIP), visto que as desordens coordenativas parecem ocorrer com mais frequência em escolares prematuros. objetivos: Descrever a coordenação motora (CM) global de crianças PT que participaram de um PIP; verificar a diferença da CM entre os sexos e correlacionar os resultados coordenativos das crianças PT com a idade gestacional (IG) e o peso ao nascimento (PN); e comparar os resultados da CM entre crianças PT e a termo (AT). Materiais e métodos: 57 crianças (5-6 anos) - 20 PT, que participaram do PIP, e 37 AT. Para análise da CM, utilizou-se o Teste de Coordenação Corporal para Crianças - Körperkoordination für Kinder (KTK). Para as comparações, utilizaram-se o Teste $t$ de Student para amostras independentes e o Teste de Mann-Whitney $(\alpha=0,05)$, além da correlação de Pearson para verificar influência da IG e do PN nos resultados coordenativos. Resultados: $80 \%$ das crianças PT demonstraram CM normal; as meninas apresentaram melhor desempenho nas tarefas trave de equilíbrio e saltos laterais e no resultado da CM correspondente ao somatório dos escores brutos das tarefas; a IG e o PN não influenciaram na CM e não houve diferença entre as CM das crianças PT e AT. Conclusão: As crianças PT apresentaram, em sua maioria, níveis satisfatórios de CM, e as meninas apresentaram melhores resultados. Além disso, a IG e o PN não interferiram nos resultados coordenativos. Por fim, não houve diferença de desempenho coordenativo entre as crianças PT e AT.

Palavras-chave: Coordenação. Habilidade motora. Prematuridade. Criança.

\section{Introduction}

Children born prematurely, who have not completed their intrauterine development, present functional and structural immaturity in their systems (1) which would be related to their greater possibility of developing: delay in their weight and height, alterations in the development of motor skills, intellectual deficiency, hearing loss, compromised visual sense, difficulty with linguistics, cardiovascular problems, respiratory problems, attention deficit, hyperactivity, among others (2-4). There is a description by the World Health Organization that classifies the premature child by their gestational age (GA), as late preterm (GA between 32 and 37 incomplete weeks); moderate preterm (GA between 28 and 32 incomplete weeks) and extremely preterm (GA under 28 weeks) (5).

In the preschool and school phases, in what we refer to as motor skills in these children, there is an emphasis on motor skills coordination (MC) and their components, such as, for example, postural balance $(3,4,6-9)$. These investigations are important, since $\mathrm{MC}$ is considered a fundamental component for the development of various motor skill abilities. Studies suggest that coordination dysfunctions appear to occur in a greater frequency in premature school children or preterm (PT) children born under weight or extremely underweight (6-8). On the other hand, a study indicated that there is no influence between the low weight at birth and the MC in a group of PT children from Portugal with ages 7 to 10 (9). The birth weight (BW) considered is classified as follows: low weight (BW $<2500 \mathrm{~g}$ ), very low weight $(\mathrm{BW}<1500$ g), and extreme low weight (BW $<1000 \mathrm{~g}$ ) (10).

As the studies indicate that PT children present a greater probability of delay in their motor skill development in short term (11-12), the investigation of MC in childhood suggests continued knowledge of its motorskills development, with the purpose of comprehending if the phenomenon of prematurity 
still exerts influence in the motor skill capacities in the long term.

One of the tests used to evaluate the MC in children is the Test of Body Coordination for Children Körperkoordination für Kinder (KTK), which is applied with children born prematurely $(6,9)$ and involves corporal coordination components such as dynamic balance, peripheral awareness, velocity, strength in inferior members, and space and time structuring. These components were distributed in four exercises: balance beam, hopping on one leg, jumping sideways and shifting platforms. These tests evaluates both global MC as well as identifies children with coordination or motor skill dysfunctions (13).

Due to the reports and stories regarding the difficulties in development of PT children, still in their school age, some authors highlight the importance of accompanying these children both through follow up or sequential programs as well as early intervention programs $(3,7,8,14)$. As the focus of this study, the early intervention programs verify the multiple risk factors and the guiding protections of development, to elaborate preventive measures and the promotion of infant development (15) including activities, opportunities, and procedures, destined to promote the development of the child. In this manner, the early intervention programs appear to allow that PT children develop motor skill strategies to perform their activities (16).

In this context, the objectives of the study were: (a) describe the global MC in children born prematurely, that participate in an early intervention program; (b) verify the difference in global MC between the sexes of PT children; (c) correlate the coordinative results of these children with perinatal variables (gestational age and birth weight); (d) Compare the results of the MC between children born PT and full-term (FT).

\section{Materials and methods}

\section{Ethical caution and characterization of the study}

The study is classified as a transversal observation type. To all the parents or legal guardians of the children it was explained the procedures of the study, and the participation of the children was guaranteed after reading and signing the Term of Clarified Free Consent. The present study was approved by the Ethical Committee in Research of the Medical School of University of Brasília (UnB), with protocol number 078/2009, according to Resolution n. 196/96.

\section{Participants}

57 children, ages 5 and 6 , of which 20 were born PT ( 9 girls and 11 boys) and 37 ( 25 girls and 12 boys) were born FT, participated in the study.

In the group of children born PT, those accompanied by the early intervention program in Ceilândia Federal District, Brazil, were also included. It were considered those that entered the program with 4 months ( \pm 2 months) and left the program with at least 3 years and 6 months ( \pm 2 months); those who presented an Apgar value in the $5^{\text {th }}$ minute $>7$, according to the summary on the hospital release form $^{1}$; and, those that evolved without neuro-motor or orthopedic alterations, according to the followup reports of the program's team. In the group of FT children, the study included those that presented an Apgar value in the $5^{\text {th }}$ minute $>7$, according to the information on the child's card. Those children that presented a dysfunction or disturbance associated with intellectual deficiency, neurological pathology, orthopedic problems, genetic syndromes, sensory dysfunctions, and congenital malformations were excluded.

\section{Early intervention program}

The early intervention program referred to in this study provides assistance to children with neuropsychomotor developmental delay in the early days/ months. Among these are those born PT that, according to the Federal District (17), are "[...] considered at risk for being vulnerable and shown delay in their global development, based on Decree 6.571/2008". The children are accompanied and encouraged from birth to 3 years and 11 months when, after this age, are sent to preschool. Throughout their stay in the program, a multidisciplinary team promotes the development of the child's strengths (17-19).

\footnotetext{
1 Document attached to the report of the infants assisted by the program.
} 
Within the early intervention program, there is a motor skills intervention made by professional involved with individual intervention for the neuromotor infant development. The activities developed aimed at multiple motor-sensory experiences.

There is a report in which documents are attached, such as medical treatment, exams performed at the Neonatal Intensive Therapy Unit, copy of the hospital release forms (filled out by the neo-natal doctor) with the pre, peri, and post natal data, as well as the periodic evaluations highlighting the evolution of neuropsychomotor development abilities. The variables GA and birth weight (BW) of the PT children were collected from the hospital release forms contained in the individual reports.

Test of Body Coordination for Children Körperkoordination für Kinder (KTK)

The KTK involves components on corporal coordination distributed into four exercises: balance beam (BB), hopping on one leg (HO), jumping sideways (JS) and shifting platforms (SP). On the balance beam, three different beams are used with widths of $6 \mathrm{~cm}$, $4.5 \mathrm{~cm}$, and $3 \mathrm{~cm}$.

The test was performed following the original descriptions with a confidence interval of 0.90 when performing the full battery of tests, which demonstrates the credibility of its application (20). The test is adequate for children from 5 to 14 years and 11 months and its application lasts approximately 10 to 15 minutes per child (13).

For the global MC classification, the original Kiphard and Schilling (20) tables were used. According to the authors, the final score of each exercise is converted into motor quotient (MQ). This procedure is performed referring to the reference tables for each test, according to the sex and age of the participant to perform a summation and obtain the total MQ. The total MQ indicates, through a reference table, to the final MQ, which allows the classification of the level of coordination performance as: insufficient coordination ( $\mathrm{MQ} \leq 70)$, coordination disturbance $(71<\mathrm{MQ}<85$ ), normal coordination (86 $<\mathrm{MQ}<115)$, good coordination $(116<\mathrm{MQ}<130)$, and very good coordination (MQ $\geq 131$ ) (13).

Even though there is no validation for various populations that participate in the studies published using KTK, including the Brazilian population, many of the studies still uses the standard tables of the test to classify the MC (21-24). Due to this fact, in the present study the tables were also used, as it describes the sum of the gross scores (Coordination) acquired in the four proposed exercises, as performed by various authors (25-26).

\section{Statistical analysis}

The study performed the descriptive analysis of the global MC and its components. The normal distribution of the data was verified using the ShapiroWilk test. To compare the results of the MC (total MQ, final MQ, and Coordination) between the sexes of the PT children, it was used the independent-samples T-test and the Mann-Whitney test. For the analysis of the correlation between the coordination components, the result of the global MC and the prenatal variables (GA and BW), the Pearson correlation test was used. In all of the situations described, the significance level considered was $5 \%$. The program used was the Statistical Package for the Social Science (SPSS) version 17.0.

\section{Results}

With regard to PT children, 16 (80\%) were classified as late premature and $4(20 \%)$ moderately premature (5). In addition to this, all were classified as underweight at birth, of which 7 (40\%) were very underweight and 1 (5\%), extremely underweight (10).

Table 1 presents the characteristics of the participating children, with birth data and the anthropometric variables collected on the day the KTK motor tests were applied. In this table, the data of the full-term group (FTG) and of the preterm group (PTG) were included, distinguished by sex.

The results of the global MC of the PT children indicate that $5 \%$ ( 1 child) presented good coordination, $80 \%$ (16 children) normal coordination, 10\% (2 children) coordination disturbance, and 5\% (1 child) insufficient coordination. As such, the majority (85\%) of the PT children demonstrated satisfactory levels (normal and good) of global MC.

Regarding the MC of boys $(\mathrm{N}=11)$ and girls $(\mathrm{N}=9$ ) born PT, only the boys presented low levels (disturbance and insufficiency) of global MC, even though in their majority, $73 \%$ (8 children) 
presented levels within normality. As for the girls, all demonstrated satisfactory levels (normal and good). The comparison between gender coordination results and its components is demonstrated in Table 2. It is important to note that total MQ and final MQ refer to the normal distribution tables of the test, and the Coordination variable to the sum of the gross scores of each test, regardless of the reference values in the KTK.

We can observe that girls presented a better performance than boys in the BB and JS tasks ( $\mathrm{p}<0.05$ ), and in the results of global MC correspond to the sum of the gross scores (Coordination) acquired in the four tasks. Regarding the BB tasks, we can note that the girls presented results significantly better on beams 1 and 2, which correspond to the 6 and 4.5 $\mathrm{cm}$ wide beams.

No statistically significant relationship was observed between the results of global MC and the prenatal variables (GA and BW), $(\mathrm{p}>0.05)$.

In the comparison between coordination performance of PT children (PTG) and full-term (FTG), the majority of children demonstrate MC within the normal distribution (FTG $=28$ kids and PTG $=16$ kids). In FTG, $16 \%$ ( 6 children) of the children presented good levels of the global MC and in counterpart 5\%
(1 child) in the PTG. The same quantity of children in both groups presented disturbance levels ( 2 children) and insufficiency ( 1 child) in the MC.

The comparison between the motor skills performance of the FTG and PTG groups is demonstrated in Table 3.

There was no significant difference between the results of the two groups analyzed, even though it appeared to exist a tendency of disadvantage in the children born prematurely, upon observing the average values of the two groups.

\section{Discussion}

According to the objectives proposed in the present study, it was established that: 1) the majority of PT children analyzed presented satisfactory global $\mathrm{MC}$, classified as normal and good, according to the criteria of the KTK; 2 ) the PT girls presented a better performance than the boys in the BB and JS tasks and in the global MC results, corresponding to the sum of the gross scores acquired in the four tasks; 3) there was no significant statistical difference between the coordination performance of the FT and PT groups of children.

Table $\mathbf{1}$ - Characteristics of the study participants (average value \pm standard deviation)

\begin{tabular}{clcccc}
\hline Groups & \multicolumn{1}{c}{ Sex } & GA (weeks) & BW $(\mathbf{g})$ & Length $(\mathbf{c m})$ & Body Mass $(\mathbf{k g})$ \\
\hline \multirow{3}{*}{ FTG } & Feminine $(\mathrm{N}=25)$ & $39.61 \pm 0.97$ & $3024.60 \pm 307.94$ & $116.16 \pm 6.05$ & $23.07 \pm 6.02$ \\
& Masculine $(\mathrm{N}=12)$ & $39.96 \pm 1.15$ & $3132.92 \pm 423.84$ & $114.54 \pm 6.62$ & $21.58 \pm 6.12$ \\
& TOTAL $(\mathbf{N}=\mathbf{3 0})$ & $39.72 \pm 1.03$ & $3059.73 \pm 347.49$ & $115.64 \pm 6.20$ & $22.58 \pm 6.01$ \\
\hline \multirow{3}{*}{ PTG } & Feminine $(\mathrm{N}=9)$ & $33.48 \pm 1.83$ & $1582.22 \pm 461.95$ & $117.78 \pm 4.40$ & $21.26 \pm 2.72$ \\
& Masculine $(\mathrm{N}=11)$ & $33.59 \pm 2.47$ & $1629.55 \pm 420.37$ & $113.55 \pm 5.07$ & $20.10 \pm 3.10$ \\
& TOTAL $(\mathbf{N}=\mathbf{2 0})$ & $33.54 \pm 2.15$ & $1608.25 \pm 428.30$ & $115.45 \pm 5.13$ & $20.62 \pm 2.92$ \\
\hline
\end{tabular}

Note: $\mathrm{FTG}=$ full-term group; PTG = PT group; $\mathrm{GA}=$ gestational age; $\mathrm{BW}=$ birth weight.

Table 2 - Scores in the battery of KTK tests of girls and boys born preterm

\begin{tabular}{|c|c|c|c|}
\hline \multicolumn{4}{|c|}{ Sex } \\
\hline \multirow{2}{*}{ Motor skill variables } & Feminine & Masculine & \multirow{2}{*}{$p$} \\
\hline & $x$ & s & \\
\hline $\mathrm{BB}$ & $33.11 \pm 9.60$ & $16.64 \pm 10.69$ & $0.00^{*}$ \\
\hline Beam 1 & $19.11 \pm 6.05$ & $9.82 \pm 6.55$ & $0.01^{*}$ \\
\hline
\end{tabular}


Table 2 - Scores in the battery of KTK tests of girls and boys born preterm

(Conclusion)

\begin{tabular}{|c|c|c|c|}
\hline \multicolumn{4}{|c|}{ Sex } \\
\hline \multirow{2}{*}{ Motor skill variables } & Feminine & Masculine & \multirow{2}{*}{$p$} \\
\hline & $\mathrm{x}$ & $x$ & \\
\hline Beam 2 & $11.22 \pm 5.17$ & $5.09 \pm 4.21$ & $0.01^{*}$ \\
\hline Beam 3 & $2.78 \pm 1.56$ & $1.73 \pm 1.74$ & 0.18 \\
\hline HO & $25.67 \pm 6.69$ & $19.45 \pm 9.92$ & 0.13 \\
\hline JS & $29.44 \pm 5.98$ & $21.27 \pm 6.10$ & $0.01^{*}$ \\
\hline SP & $42.78 \pm 3.15$ & $37.91 \pm 7.84$ & 0.24 \\
\hline Coordination & $131 \pm 16.38$ & $95.27 \pm 31.44$ & $0.00^{*}$ \\
\hline MQ total & $413.11 \pm 18.86$ & $386 \pm 39.96$ & 0.23 \\
\hline$M Q$ final & $104.11 \pm 6.15$ & $95.55 \pm 12.95$ & 0.22 \\
\hline
\end{tabular}

Note: $\mathrm{BB}=$ Balance beam (Beam $1=6 \mathrm{~cm}$ wide beam; Beam $2=4.5 \mathrm{~cm}$ wide beam; Beam $3=3 \mathrm{~cm}$ wide beam); $\mathrm{HO}=$ hopping on one leg; $\mathrm{JS}=$ jumping sideways; $\mathrm{SP}=$ shifting platforms; $\mathrm{MQ}$ total = total motor quotient; $\mathrm{MQ}$ final = final motor quotient; $\mathrm{X}=$ average; $S=$ standard deviation; ${ }^{*} p<0.05$.

Table 3 - Scores in the battery of KTK tests of the groups of children preterm (PTG) and full-term (FTG)

\begin{tabular}{|c|c|c|c|}
\hline \multicolumn{4}{|c|}{ Classification } \\
\hline \multirow{2}{*}{ Variables motor skill } & FTG $(N=37)$ & PTG $(N=20)$ & \multirow{2}{*}{$p$} \\
\hline & $x$ & $\mathrm{x}$ & \\
\hline BB & $23.97 \pm 11.37$ & $24.05 \pm 13.02$ & 0.98 \\
\hline Beam 1 & $14.35 \pm 6.69$ & $14.00 \pm 7.78$ & 0.86 \\
\hline Beam 2 & $6.57 \pm 3.93$ & $7.85 \pm 5.51$ & 0.49 \\
\hline Beam 3 & $3.05 \pm 2.43$ & $2.20 \pm 1.70$ & 0.27 \\
\hline HO & $24.24 \pm 12.54$ & $22.25 \pm 8.98$ & 0.53 \\
\hline JS & $25.05 \pm 7.66$ & $24.95 \pm 7.21$ & 0.96 \\
\hline SP & $42.14 \pm 5.91$ & $40.10 \pm 6.54$ & 0.50 \\
\hline Coordination & $115.41 \pm 29.75$ & $111.35 \pm 31.08$ & 0.63 \\
\hline $\mathrm{MQ}$ total & $407.22 \pm 41.58$ & $399 \pm 35.54$ & 0.46 \\
\hline MQ final & $102.22 \pm 13.42$ & $99.65 \pm 11.48$ & 0.47 \\
\hline
\end{tabular}

Note: $\mathrm{BB}=$ Balance beam (Beam $1=6 \mathrm{~cm}$ wide beam; $\mathrm{Beam} 2=4.5 \mathrm{~cm}$ wide beam; Beam $3=3 \mathrm{~cm}$ wide beam); $\mathrm{HO}=$ hopping on one leg; JS = jumping sideways; $\mathrm{SP}=$ shifting platforms; $\mathrm{MQ}$ total = total motor quotient; $\mathrm{MQ}$ final $=$ final motor quotient; $\mathrm{X}=$ average; $S=$ standard deviation

Matos' study (9) analyzed global MC, using KTK, of 31 PT children and very underweight, from ages 7 to 10 years. $71 \%$ of the children presented a coordination insufficiency, and only $6 \%$ presented a normal level of global MC. Even though they used the same instrument to evaluate global MC, the samples of the Matos study (9) and the present study are different, because, in the first, the children were recruited from the National Registry of New-Borns that are Very Under Weight (Portugal) without having participated 
in an early intervention program, as occurred with the participants of this study.

The Keller et al. study (6) also analyzed the coordinative performance using KTK of 20 PT children born very underweight and 14 extremely underweight, between the ages of 5 and 7 years old. The results indicate worse average values demonstrated by the children born extremely underweight and with younger gestational ages. In the study referenced, the children had also not participated in an early intervention program, only in a follow-up program, with no indication of any type of proper intervention during the studies performed in the first three years of life.

There is a difficulty in finding in the literature available studies that demonstrate the coordination performance of children born PT that participated in an early intervention program, as in the case of the present study. For them, various experiences were offered, primarily related to motor skill dominion as seen that good motor skill development reverberates in the future life of the child in their social, intellectual, and cultural aspects, as the characteristic of the presence of a motor skill deficiency results in the child seeking refuge from any environment in which they do not dominate, and consequently they forgo experiencing, or experience in a lesser frequency, certain activities (27). In addition, the studies mentioned include PT children born very underweight (BW < 1500 g) and/or extremely underweight ( $B W<1000 \mathrm{~g}$ ), variables that increase the degree of compromised motor-function according to various authors $(6-8,28,29)$. These variables were not frequent in the present study since the majority $(55 \%)$ of the children presented a birth weight between $1500 \mathrm{~g}$ and $2500 \mathrm{~g}$.

In this study, the girls presented better results than the boys in the BB and JS tasks. The first task involves dynamic balance and the second involved velocity. The effect of the BB task was influenced by the results of the balancing beams ( 6 and $4.5 \mathrm{~cm}$ widths). In addition to this, the PT girls presented, in a general manner, coordination performance better than the boys, since there was a significant difference between the Coordination variable. This fact did not occur in the total MQ variable to which it is related to the normative data of the test. Perhaps the summary of the gross values in the four tasks is more sensitive to identify the coordination differences in the populations that have yet to have KTK validation.
A difference in the performance between the sexes was registered in studies regarding motor skill development in PT children $(4,6,7,9,30-32)$. The Matos study (9) verified that the girls between 7 and 8 years presented superior scores than the boys in the KTK tasks, with the exemption of the SP task. But, with a significant result only in BB test, as presented in this study. It seems that PT girls presented better performance in the dynamic balancing task in early or late ages. On the other hand, the Keller et al. (6) study does not demonstrate a significant difference between the genders in the three tasks applied with KTK.

There is still no consensus regarding the difference in coordination behavior between girls and boys born prematurely. And, unfortunately, an account of the use of KTK tests in PT children ages 5 to 6 years old was not found, which makes it difficult an effective comparison between studies. However, the data presented appear to indicate that PT girls evaluated present a better compensation of their motor skills in spite of the prematurity variable. As they have their balance approximately $50 \%$ better than boys $(\mathrm{p}<$ 0.00 ), the PT girls studied appear to present a better capacity to adjust their posture to compensate disturbances in their balance evoked by the proposed movement. The same adjustment can be related to the results found in the velocity variable, in the JS task. In this perspective, the male sex seems to be a risk factor for the development of premature children and the female sex a protective factor (33).

As no significant difference was observed between the prenatal variables (GA and BW) and the coordination performance results of the PT children, it can be suggested that the level of prematurity (average of 33 weeks from gestation age) appears to not influence global MC. Likewise, an average weight at birth of $1,608 \mathrm{~g}$ also appears to not interfere in the coordination results. A similar result was observed by Matos (9) who also emphasized that even considering a very low birth weight $(<1500 \mathrm{~g})$, a significant correlation of this variable and global MC at ages 7-10 years was not observed.

The study observed that a percentage of FT children $(16 \%)$ presented a good level of MC in relation to the PT children studies (5\%). In both groups, FTG and PTG, the majority of the children demonstrated a normal level of coordination. A difference between the groups in relation to individual results in the KTK tasks and the global MC results was not observed. In the Keller et al. (6) study, the scores of 
the BB task were low, but without a significant difference, both in the underweight group as well as the extremely underweight group, with lower gestational ages, when compared to children born with proper weight. In the tasks involving jumping (HO and JS), the worst performance was presented by children with extremely low birth weight. And in the SP task, the results were similar for the three groups. The study suggests that the smallest neuromotor capacity of PT children and low birth weight, in combination with a prenatal course, appears to result in a motor skill deficiency at the ages of 5 to 7 years even when they do not present any ostensive neuromuscular deficiency. The Hebestreit et al. study (34), also utilized the KTK tests to compare global MC in 33 PT children, ages 6-11 years, with 21 FT children. None of the children presented dysfunctions or limited motor skills. The results of the PT children (final MQ = $92.4 \pm 15.4)$ were inferior $(\mathrm{p}<0.05)$ to those born FT (final MQ $=102.5 \pm 13.6$ ).

In both the studies mentioned, the variables of very low weight and extreme low weight at birth were present. Other studies also performed the comparison of MC between PT and FT children in school age and found worse performance results in the PT children $(4,8,31)$.

According to what is observed in both national and international literature, the children with a history of prematurity appear to present worse motor skills performance when they reach school age. Many of the studies that present disadvantages in the motor skill performance of PT children include in their samples children born very underweight or extremely underweight at birth, what has already been mentioned as being a high risk for limited development. In addition, these variables appear to not be compensated by the children participating in an intervention program (35-37).

For these motives, authors frequently cite the importance of following the development of these children until school age $(7,8,14,32,38,39)$. There also exists those that highlight the importance of intervention programs with preventative objectives for PT children and/or those children of low weight (3, $32,36,38)$.

The results of the present study appear to indicate that even regarding the tendency observed, including in the literature consulted, of PT children presenting a disadvantage in the coordination behavior when compared to FT children, a statistically significant difference between the children studied was not observed. This fact indicated that the groups of children demonstrate performance similar to the dominion of global MC, which leads to the possibility of believing that the early intervention program provided for the PT kids in their first years of life influenced the results found. It appears to be a cumulative effect in the experiences offered by the program to the PT children studied, as an incentive process for the childhood development promoted by the program, since the criteria of the evaluation in the first years of life could determine a proper intervention, with the aim of children with a diagnosed delay may follow the same sequence as those children with normal development (40). In addition to this, according to Bonnier (41), the early intervention program appear to be designated for educational and neuro-protection strategies to promote brain development, being, in a certain way, linked to the process of cerebral plasticity.

Authors indicate that PT babies present a postural behavior related to a deficient muscular force to a delay in dynamic balance, to delay in walking independently, and a poor quality in initial gait (42). Maybe with the initial identification of these factors in conjunction to an adequate motor skill intervention and observation, the PT children pass through a process of motor skill "compensation" and can reach the adequate performance for their development.

Upon considering that the early intervention program spans diverse aspects of infant development, it is believed that multiple experiences were induced for the PT children of this study. It appears that a stimulating environment that facilitates infant development enriches their motor-sensory experiences $(16,43)$. These experiences could have influenced the results encountered. Also, the studies explored by Ballestero (44), in his literature revision, demonstrated that early intervention programs may cause an improvement or progression in MC in a general manner. In addition, the experiences in the first three years of life promotes a unique force in the brain development of humans, which facilitates the formation of neuronal circuits (45).

\section{Conclusion}

The data from the present study describes the levels of body coordination of preterm children recruited from an institution that promoted a program 
to enhance children's skills. As a result, the majority of these children had satisfactory levels of coordination and the girls demonstrated better results. It was observed that gestational age and birth weight did not interfere in coordinative results. Finally, there was no difference in coordinative performance between preterm and full term infants, suggesting a facilitation of the infant development promoted by early intervention programs. There are few reports of motor skill coordination in children in school age that were born prematurely and participated in early intervention programs in the first years of their lives. All in all, new studies are recommended to perform a longitudinal registry, including not only the motor skill but also the cognitive and behavioral features, since these last two aspects, according to the literature, also appear to be influenced by early intervention programs in infants.

\section{References}

1. Rugolo LMSS, editor. Manual de neonatologia. 2. ed. Rio de Janeiro: Revinter; 2000.

2. Hack M. Young adult outcomes of very-low-birthweight children. Semin Fetal Neonatal Med. 2006; 11(2):127-37.

3. Magalhães LC, Catarina PW, Barbosa VM, Mancini MC. Estudo comparativo sobre o desenvolvimento perceptual e motor na idade escolar em crianças nascidas pré-termo e a termo. Arq Neuropsiquiatr. 2003;61(2-A):250-5.

4. Foulder-Hughes LA, Cooke RW. Motor, cognitive, and behavioural disorders in children born very preterm. Dev Med Child Neurol. 2003;45(2):97-103.

5. World Health Organization. Born too soon: the global action report on preterm birth. Geneva: WHO; 2012.

6. Keller H, Ayub BW, Saigal S, Bar-Or O. Neuromotor ability in 5- to 7-year old children with very low or extremely low birthweight. Dev Med Child Neurol. 1998;40(10):661-6.

7. Davis NM, Ford GW, Anderson PJ, Doyle LW; Victorian Infant Collaborative Study Group. Developmental coordination disorder at 8 years of age in a regional cohort of extremely low-birthweight or very preterm infants. Dev Med Child Neurol. 2007;49(5):325-30.
8. Magalhães LC, Rezende FCA, Magalhães CM, Albuquerque PDR. Análise comparativa da coordenação motora de crianças nascidas a termo e pré-termo, aos 7 anos de idade. Rev Bras Saúde Matern Infant. 2009;9(3):293-300.

9. Matos CSDG. Coordenação motora: estudo em crianças ex-prematuras nascidas com muito baixo peso [dissertação]. Porto: Universidade do Porto; 2009.

10. DATASUS. Informações de Saúde [Internet]. Brasília: Minstério da Saúde; 2012 [cited 2015 Feb 9]. Avaliable from: http://www2.datasus.gov.br/DATASUS/ index.php?area $=02$

11. Gaetan EM, Moura-Ribeiro MVL. Developmental study of early posture control in preterm and fullterm infants. Arq Neuropsiquiatr. 2002;60(4):954-8.

12. Silva ES, Nunes ML. The influence of gestational age and birth weight in the clinical assessment of the muscle tone of healthy term and preterm newborns Arq Neuropsiquiatr. 2005;63(4):956-62.

13. Gorla JI, Araújo PF, Rodrigues JL. Avaliação motora em educação física adaptada: teste KTK para deficientes mentais. São Paulo: Phorte; 2009.

14. Dall'oglio AM, Rossiello B, Coletti MF, Bultrini M, de Marchis C, Ravà L, et al. Do healthy preterm children need neuropsychological follow-up? Preschool outcomes compared with term peers. Dev Med Child Neurol. 2010;52(10):955-61.

15. Formiga CKMR, Pedrazzani ES. A prevenção de deficiências no alvo da educação especial. Rev Bras Ed Esp. 2004;10(1):107-22.

16. Ribeiro ASC, Borges MBS, Formiga CKMR. Desenvolvimento motor de prematuros participantes de um programa de intervenção precoce. Fisioter Bras. 2010;11(4):271-6.

17. Distrito Federal. Secretaria de Estado da Educação. Educação Especial. 2010 [cited 2010 Apr 4]. Avaible from: www.se.df.gov.br/component/content/article/ 255_educacao_especial.html

18. Distrito Federal. Programa de Estimulação Precoce. Brasilia: Governo do Distrito Federal; 2004.

19. Governo do Distrito Federal. Orientação Pedagógica. Brasília: Governo do Distrito Federal; 2010.

20. Kiphard EJ, Schilling VF. Körper-koordinations-test für kinder: KTK. Weinhein: Beltz Test; 1974. 
21. Collet C, Folle A, Pelozin F, Botti M, Nascimento JV. Nível de coordenação motora de escolares da rede estadual da cidade de Florianópolis. Motriz: Rev Educ Fis. 2008;14(4):373-80.

22. Carminato RA. Desempenho motor de escolares através da bateria de teste KTK [dissertação]. Curitiba: Universidade Federal do Paraná; 2010.

23. Lopes LO, Lopes VP, Santos R, Pereira BO. Associações entre actividade física, habilidades e coordenação motra em crianças portuguesas. Rev Bras Cineantropom Desempenho Hum. 2011;13(1):15-21.

24. Pelozin F, Folle A, Collet C, Botti M, Nascimento JV. Nível de coordenação motora de escolares de 9 a 11 anos da rede estadual de ensino da cidade de Florianópolis/SC. Rev Mackenzie Educ Fis Esporte. 2009;8(2):123-32.

25. Valdivia AB, Cartagena LC, Sarria NE, Távara IS, Seabra AFT, Silva RG, et al. Coordinación motora: influencia de la edad, sexo, estatus socio-económico y niveles de adiposidad en niños peruanos Rev Bras Cineantropom Desempenho Hum. 2008;10(1):25-34.

26. Catenassi FZ, Marques I, Bastos CB, Basso L, Ronque ERV, Gerage AM. Relação entre índice de massa corporal e habilidade motora grossa em crianças de quatro a seis anos. Rev Bras Med Esporte. 2007;13(4):227-30.

27. Vigiano AP, Reis CB, Recalde CSS, Mello JISC, Suenari L, Affara CR. A importância em estimular as fases do desenvolvimento motor normal de 0 a 18 meses. Fisioter Mov. 1998;10(2):31-43.

28. Kieviet JF, Piek JP, Aarnoudse-Moens CS, Oosterlaan J. Motor development in very preterm and very low birth weight children from birth to adolescence: a meta-analysis. JAMA. 2009;302(20):2235-42. doi: 10.1001/jama.2009.1708.

29. Spittle A, Orton J, Doyle LW, Roslyn B. Early developmental intervention programs post hospital discharge to prevent motor and cognitive impairments in preterm infants. Cochrane Database of Syst Rev. 2007;18(2):CD005495.

30. Elliman AM, Bryan EM, Elliman AD, Walker J, Harvey DR. Coordination in LBW seven year olds. Acta Paediatric. 1991;80(3):316-22.

31. Foulder-Hughes L, Cooke R. Do mainstream schoolchildren who were born preterm have motor problems? Br J Occup Ther. 2003;66(1):9-16.
32. Powls A, Botting N, Cooke RWI, Marlow N. Motor impairment in children 12 to 13 years old with a birthweight of less than $1250 \mathrm{~g}$. Arch Dis Child Fetal Neonatal Ed. 1995;73(2):F62-6.

33. Cunha AL, Fernandes DS, Melo PF, Guedes MH. Fatores associados à asfixia perinatal. Rev Bras Ginecol Obstet. 2004;26(10):799-805.

34. Hebestreit H, Dietz S, Hierner A, Schrank W, Schoro L, Strasburg HM. Body coordination and mechanical efficiency in children born prematurely [abstract]. Pediatr Exerc Sci. 1999;11(3):304.

35. Brooks-Gunn J, McCarton CM, Casey PH, McCormick MC, Bauer CR, Bernbaum JC, et al. Early intervention in low birth weight premature infants. JAMA. 1994; 272(16):1257-62.

36. McCarton CM, Brooks-Gunn J, Wallace IF, Bauer CR, Bennett FC, Bernbaum JC, et al. Results at age 8 years of early intervention for low birth weight premature infants. JAMA. 1997;277(2):123-32.

37. Lee SY, Chow CB, Ma PY, Ho YB, Shek CC. Gross motor skilss of premature, very low-birthweight Chinese children. Ann Trop Paediatr. 2004;24(2):179-83.

38. Magalhães CM, Barbosa VM, Lopes KC, Paixão ML. Estudo longitudinal do desenvolvimento de recémnascidos pré-termo: avaliação na idade pré-escolar. Rev Bras Neurol. 1999;35(4):87-93.

39. Majnemer A. Motor incoordination in children born preterm: coordinated efforts needed. Dev Med Child Neurol. 2007;49(5):324.

40. Willrich A, Azevedo CCF, Fernandes JO. Desenvolvimento motor na infância: influência dos fatores de risco e programas de intervenção. Rev Neurocienc. 2009;17(1):51-6.

41. Bonnier C. Evaluation of early stimulation programs for enhacing brain development. Acta Paediatr. 2008;97(7):853-8. doi: 10.1111/j.1651-2227. 2008.00834.x.

42. Fallang B, Hadders-Algra M. Postural behavior in children born preterm. Neural Plast. 2005;12(2-3):175-82.

43. Formiga CKMR. Programa de intervenção com bebês pré-termo e suas famílias: avaliação e subsídios para prevenção de deficiências [dissertação]. São Carlos: Universidade Federal de São Carlos; 2003. 
44. Ballestero CLG. Avaliação da coordenação motora, ideais fundamentais e investigação empírica a partir da bateria de teste KTK [dissertação]. Porto: Universidade do Porto; 2008.

45. Montagno EA. Aprendendo quando somos jovens [internet]. Cérebro e Mente. 1997 [cited 2015, Feb 5];3. Avaliable at: http://www.cerebromente.org.br/n03/ opiniao/elson1.htm

Received: 01/12/2014

Recebido: 12/01/2014

Approved: 08/11/2014

Aprovado: 11/08/2014 